\title{
Assessing site potential, sequence and looting damage of the Palaeolithic deposits at La Cova del Moro (El Poble Nou de Benitatxell, Alicante, Mediterranean Iberia)
}

\author{
Avaluant el potencial, la seqüiència i els danys clandestins \\ dels dipòsits paleolítics de La Cova del Moro (El Poble Nou \\ de Benitatxell, Alacant, Mediterrània ibèrica)
}

\section{DíDAC ROMÁN}

Pre-EINA-Universitat Jaume I. Departament d'Història, Geografia i Art Av. Sos Baynat, s/n, E-12071 Castelló de la Plana romand@uji.es

\section{JOAQUIM BOLUFER}

Museu Arqueològic i Etnogràfic «Soler Blasco»

Plaça dels Germans Segarra, 1, E-03730 Xàbia

mvsev.xabia@gmail.com

INÉS DOMINGO

ICREA - Universitat de Barcelona. SERP. Secció de Prehistòria i Arqueologia

C/ Montalegre, 6, E-08001 Barcelona

ines.domingo@ub.edu

Cristina ReAL

Universitat de València. Departament de Prehistòria, Arqueologia i Història Antiga

Av. Blasco Ibañez 28, E-46010 València

cristina.real@uv.es

\section{Alfred SANCHIS}

Museu de Prehistòria de València. Servei d'Investigació Prehistòrica. Diputació de València $\mathrm{C} /$ de la Corona 36, E-46003 València

alfred.sanchis@dival.es

YolANDA CARRIÓN MARCO

Universitat de València. Departament de Prehistòria, Arqueologia i Història Antiga

Av. Blasco Ibañez 28, E-46010 València

yolanda.carrion@uv.es 
This paper assesses the potential and sequence of the Palaeolithic human occupations at La Cova del Moro site and the effects of the irretrievable damage caused by anthropogenic processes, including illicit excavations and urban development. While the site was discovered in 1898, it was never excavated with scientific methods, despite being located in an area of Mediterranean Iberia renowned for the high density of Upper Paleolithic sites. Information collected from looters trenches to clarify the sequence and quantify the damages, first radiocarbon dates and full analysis of the materials recovered have been central to this assessment and provide the foundation for future controlled excavations. The results show that the site preserves a long Upper Palaeolithic sequence.

\section{KEYWORDS}

UPPER PALAEOLITHIC, MEDITERRANEAN IBERIA, ETHICS, CONSERVATION

Aquest treball avalua el potencial i la seqüència de les ocupacions paleolítiques del jaciment de La Cova del Moro i els efectes del dany irreparable causat pels processos humans, inclosos les excavacions clandestines i el desenvolupament urbanístic. Tot i que el lloc va ser descobert el 1898, mai no ha estat excavat amb mètodes científics, tot i estar situat en una zona de la Mediterrània ibèrica amb una densitat de jaciments del Paleolític superior. La informació recollida en la zona afectada pels saquejadors per aclarir la seqüència i quantificar els danys, les primeres datacions de radiocarboni i l'anàlisi completa dels materials recuperats han estat fonamentals per a aquesta avaluació i proporcionen les bases per a futures excavacions controlades. Els resultats mostren que el jaciment conserva una llarga seqüència del Paleolític superior.

PARAULES CLAU

PALEOLÍTIC SUPERIOR, MEDITERRÀNIA IBÈRICA, ÈTICA, CONSERVACIÓ

\section{Introduction}

This paper releases the results of the urgent assessment and preliminary study of La Cova del Moro site (El Poble Nou de Benitatxell, Alicante) following an initiative of the local city council, together with the Museum of Xàbia, interested in verifying the historical, cultural and scientific values and the archaeological potential of this site and in quantifying the damage caused by continuing illicit excavations and urban development.

As early as 2005, the director of the Museum of Xàbia, J. Bolufer, reported on successive unauthorized excavations and looting. At the time he estimated that nearly $50 \%$ of the site was already destroyed (Bolufer, 2005). The lack of physical protection measures has compromised the site, facilitating unregulated access. Unfortunately, the incidents of vandalism have continued to date. As we have witnessed during our recent visit to the site in 2016, some of the long bones visible on the right side of the section of one of the two looter's trenches identified during a previous visit to the site in 2008, were now missing. This recurrent misuse of the site demonstrates that the physical protection of the entrance is becoming urgent if we are to ensure the integrity and values of these unique prehistoric deposits. 
Today, 172 years after the discovery, and with materials of this site held in the collections of some of the most renowned Spanish museums (initially the Museum of Natural Sciences and, later on the National Archaeological Museum, both in Madrid) (Castaño et al., 2008), it is surprising to discover that this site has never been excavated with archaeological methodology, even though previous studies already reported the presence of upper Paleolithic deposits (Casabó, 1990).

In our previous review of the materials recovered after several clandestine digs, and those collected by Vilanova i Piera at the end of the 19th century (Castaño et al., 2008), we inferred that the cavity could possibly hold a long Palaeolithic sequence. Only a few remains suggested some later occupations, a priori with low potential to cause significant disturbances to the Paleolithic deposits. Our first approach based on materials recovered out of context confirmed the need to clarify the sequence through an in situ analysis of the stratigraphy, visible in the sections of the two looters trenches today still opened at the site. Thus, the aim in this new phase of study was:

- to clarify the sequence, by cleaning the surface of the site sections visible in two over a meter depth looter's trenches, and analyze them in detail,

- obtaining a battery of radiocarbon dates taking samples from the freshly cleaned sections to better link the archaeological finds to numeric age estimates,

- and to fully analyze the materials recovered both from the cleaning of the sections and from the bottom of the looter's trenches. The finds include lithic and bone industry, as well as faunal and anthracological remains.

This first approach was necessary to assess the potential of the archaeological deposits, to suggest the adoption of urgent measures to protect the site and mitigate the impact of unauthorized visits, and to come up with an action plan for future excavations to advance our understanding on human settlements and practices during the upper Palaeolithic in Mediterranean Iberia. This first approach was conducted in 2016 supported by Poble Nou de Benitatxell city council.

In addition, and considering the promising results of this study, we appeal to the authorities responsible of the cultural heritage located in Valencian Country, to urgently proceed to the physical protection of this site by fencing the entrance, to regulate the illicit access to this Paleolithic site and to stop the recurrent acts of vandalism threatening the long-term preservation of this prehistoric heritage. In 2014, urban waste coming from a nearby urbanization were about to bury the entrance to the cave (fig. 2). These continuous threats have been reported to the public authorities responsible for cultural heritage on several occasions, without any practical steps toward the protection of the site so far. In 2005 it was requested for the site to be included in the catalog of cavities of the valencian government (Conselleria de Territori i Habitatge) considering the archaeological and environmental interest of the site, as well as the risk of destruction that the urban development of the area can bring. However, this demand didn't get a positive response and the site was not included in the above mentioned catalog. 
The protection of the archaeological heritage is an obligation of the public administrations at the national, regional and local level, as established by the Spanish Historical Heritage Act, 16/1985, June 25th. Actions should be taken to keep prehistorical sites, and especially those with the potential of La Cova del Moro, from being destroyed as a result of administrative inactions. This inaction cannot continue being an option, especially after the number of reports and calls from archaeologists and local institutions describing recurrent illicit activities threatening the future of the site. This paper also seeks to call upon the governments to immediately protect La Cova del Moro site.

\section{La Cova del Moro: Geographic location and brief description of the site}

La Cova del Moro is located in the municipality of El Poble Nou de Benitatxell (Alicante, Spain) (fig. 1). The cave is part of the karstic system of the area. The entrance faces East on the right side of the Les Raboses ravine (fig. 2).

The cave is divided into two areas (fig. 3). The first one could be described as a deep shelter, about two meters high in the mouth and 5 meters deep, with an area of about $35 \mathrm{~m}^{2}$. This area is practically empty today, but the lack of sediments is probably due to the use of these sediments by farmers to build agricultural terraces during the late nineteenth century (Bolufer, 2005).

The second room is a cave, and it can be accessed through a small descending tunnel. This tunnel runs partially among fallen rocks, and it gives access to an elongated

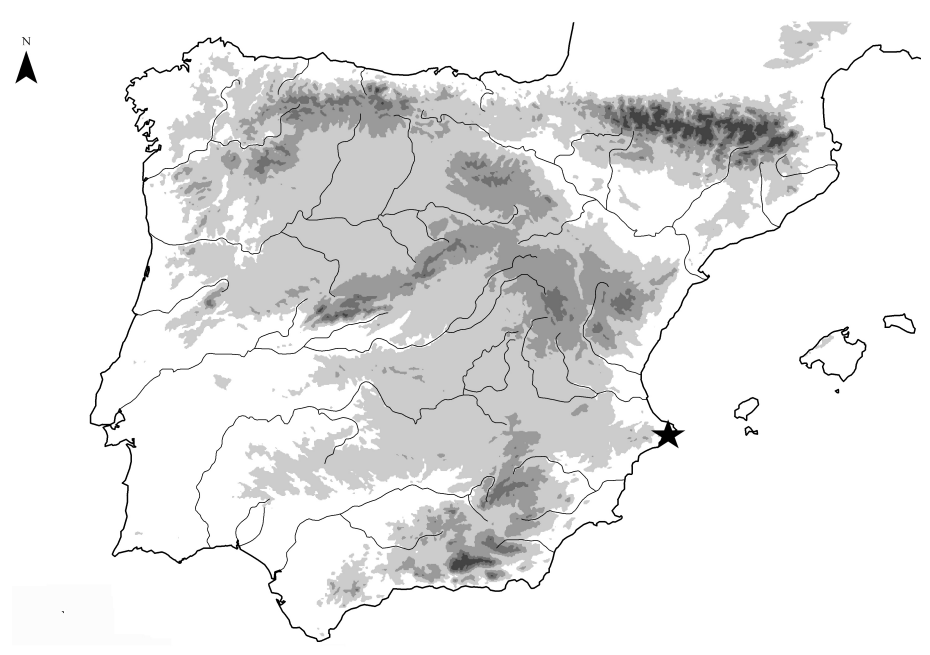

Figure 1. La Cova del Moro situation. 
Figure 2. La Cova del Moro entrance.

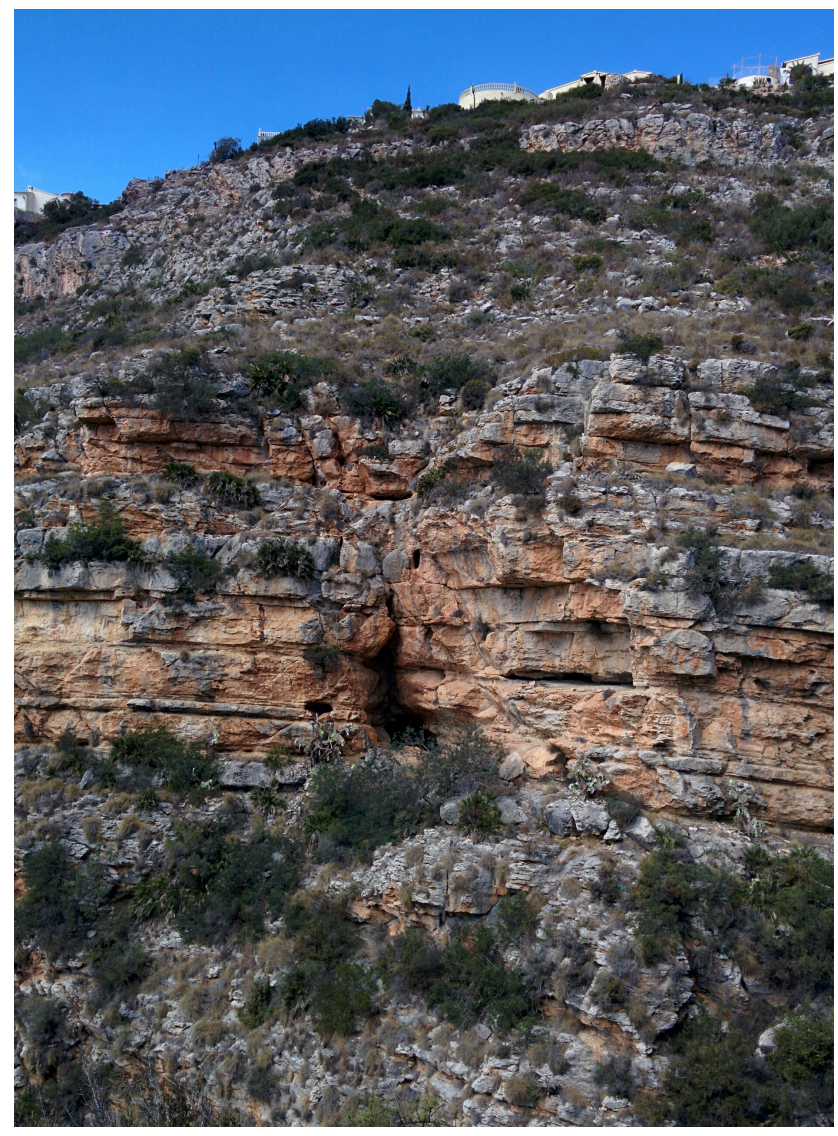

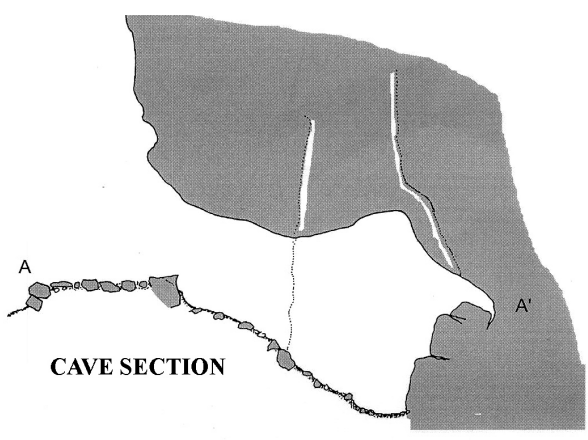

\begin{tabular}{lll}
0 & 1 & 2 \\
\hline
\end{tabular}

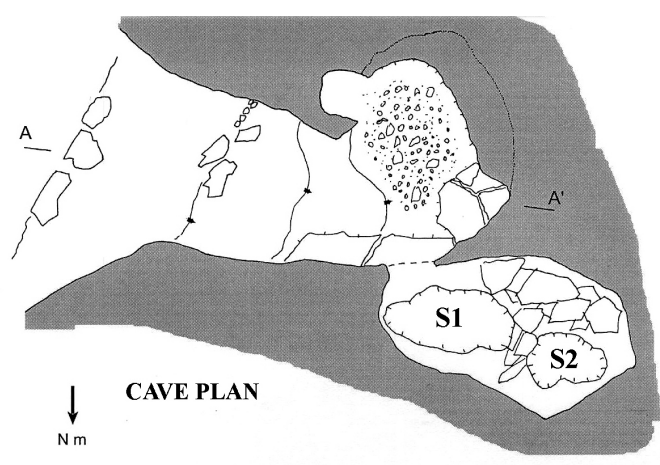

LA COVA DEL MORO Poble Nou de Benitatxell

Figure 3. La Cova del Moro plan and section. 


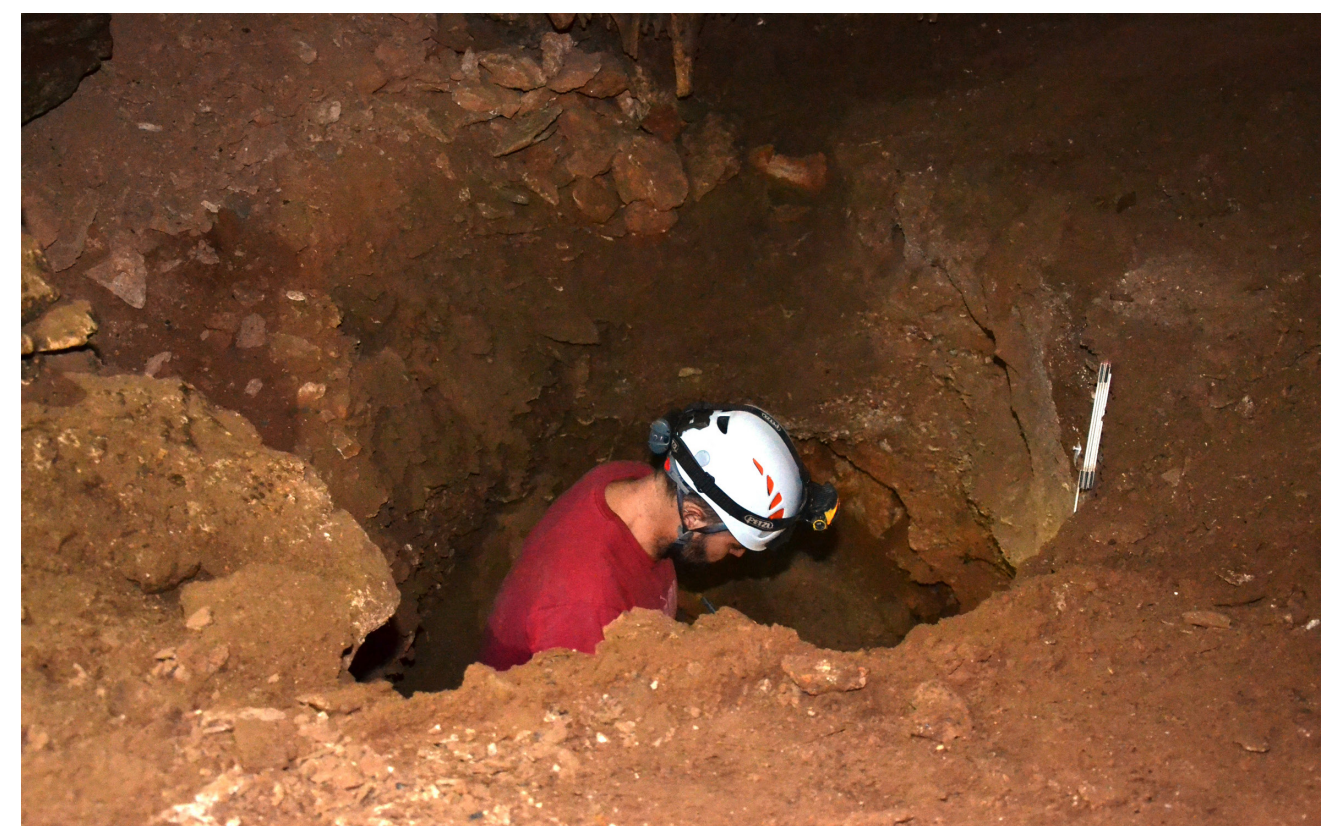

Figure 4. Looter excavation pit at the bottom of the cave ("S2" in figure 3).

and descending room measuring $8 \mathrm{~m}$ long and 3,5 $\mathrm{m}$ width. This space preserves a large deposit, that could potentially be larger, since through a still inaccessible small tunnel we roughly identify another small adjacent room.

In this inner cavity, two large trenches, more than one meter deep each, opened by illicit excavations, expose two stratigraphic sections (fig. 4). In both sections at least two large sedimentary levels, with alternating colours and textures are evident. Archaeological remains and patches of charcoal are also visible from top to bottom. Our 2016 fieldwork campaign aim at cleaning these two sections, to facilitate systematic analysis, recording and sampling for radiocarbon dating with the idea of clarifying the number and chronologies of the prehistoric human occupations.

\section{Archaeological background}

La Cova del Moro site was scientifically discovered at the end of the 19th century by geologist and palaeontologist J. Vilanova i Piera (Castaño et al., 2008). The site was explicitly mentioned in the speech given on his admission to the Royal Academy of History (Vilanova, 1889). Both in this speech and in a later publication (Vilanova \& Rada, 1892), 
Vilanova describes the materials recovered at this and other sites of this region as belonging to an ancient phase he called Mesolithic (Castaño et al., 2008: 3). Interestingly some of the other caves he mentioned at the time, are now attributed to the Upper Palaeolithic, such as the cave of Parpalló, famous for providing a unique collection of more than 6000 pieces of Palaeolithic portable art (Villaverde, 1994). A year after his death, in 1893, the National Anthropological Museum bought Vilanova's archaeological collection (1894), including, among others, the remains recovered in la Cova del Moro. The inventory coming with the collection of materials from this site describes them as follows: "lithic industry: burins, retouched and unretouched blades and flakes, bone industry / ornamental items: pendant made on shell; macrofauna: dental pieces, complete and fragmented vertebrae, fragments of mandible, sacrum, skull, fused ribs; Malacofauna: shell fragment; Minerals: fragment of breccia and quartz (Prieto, 2017: 23). Later on, in 1940, and shortly before the reassignment of Vilanova's archaeological collection from the Anthropological Museum to the National Archaeological Museum (MAN) in 1942, D. Fletcher made a brief inventory of the finds, noting the presence of "archaeolithic flints, some human bones, other mammals, land snails and other seashells“ (Fletcher, 1945: 348). These early publications didn't include, however, any explicit reference to Upper Palaeolithic human occupations.

From there on the site is indiscriminately visited by amateurs and looters, conducting illicit excavations and plundering. In 1990 J. Casabó studied part of the decontextualized materials uncovered and left on the surface of the site during the unauthorized excavations, and subsequently recovered and kept at the local Museu Soler Blasco of Xàbia (Casabó, 1992). In his paper, he dates the site back to the Upper Palaeolithic for the first time, based on the identification of a fragment of a laurel leaf point, characteristic of the Solutrean.

Nevertheless, up until 2005 the site is not properly documented, and it is right then when the current director of the Museu Soler Blasco of Xàbia, J. Bolufer, produces the first site plans of the cave. He also includes a brief description and provides exact data about the location. He also prepares a report assessing the state of conservation and denouncing that the archaeological deposits are seriously affected by looting and that the site is in danger due to the urban over-exploitation of the area (Bolufer, 2005).

Finally, it is this danger of destruction what leads to a complete study of the materials recovered to date and kept at the Museu Soler Blasco of Xàbia and the National Archaeological Museum of Madrid. In this last study we conducted an in-depth analysis of both the lithic industry and the faunal remains, concluding that the site very likely preserved a long upper Palaeolithic sequence, even though just the Solutrean levels, belonging either to the middle or the upper Solutrean, could be fully confirmed based on the fragment of the laurel leaf point previously mentioned.

In addition, it was concluded that the faunal remains could reflect the hunting patterns of the end of the Paleolithic, potentially the Magdalenian (Castaño et al., 2008). But the proposed synthesis had to be verified and supported by a more comprehensive 
analysis of the stratigraphy to confirm the sequence. This paper presents the results of this further step.

\section{Conservation status of the site}

Understanding the integrity of the Palaeolithic deposits at La Cova del Moro site was one of the primary aims of this exploratory stage. While the current state of conservation of la Cova del Moro site is particularly worrying, due to continuous illicit excavations and other human impacts, it doesn't dismiss the significance of the site for upper Palaeolithic research. First, it is important to note that the external room was emptied at the end of the 19th century as a result of the construction of agricultural terraces on the slopes of the ravine (Bolufer, 2005). At a later time and on several occasions during the past century clandestine excavations have caused significant disruptions to the internal room. The lack of physical protection have contributed towards these acts of vandalism. And all this preceded by several warnings to the Territorial Services of Archaeology, of the Consellería de Cultura (the regional government to whom competences have been transferred regarding the protection of the cultural heritage in this region) that so far have failed to take action to protect whatever remains of the Palaeolithic occupations.

The second last aggression was in 2014, when urban development works were being conducted on the top of the cliff in which the entrance is located (fig. 2). At that time uncontrolled dumping of debris, stones and dirt, nearly buried the access-Levante-EMV news on 03/30/2014. This aggression was reported both to the Seprona (Nature Protection Service) of the Civil Guard (a unit responsible for nature protection and management, also involved in operations against site looting and illicit trade or antiquities) and to the Jucar Hydrographic Confederation, responsible for the river basin management and perimeter protection. This aggression was the reason behind the local government's request to prepare the current report on the state of conservation and the potential and values of the site, resulting in this paper.

Unfortunately, this has not been the last aggression, since in 2016, during the cleaning of the sections and the sieving of part of the sediments uncovered during previous illicit excavations, we noticed that some of the bones visible in the site sections back in 2008 were now missing. Disappearance of these particular remains demonstrates that unregulated visits to the site continue today, further damaging the archaeological deposits still preserved. Thus, fencing the site is today an urgent priority.

Altogether, if we consider both rooms, the destruction of the archaeological deposits can be estimated in more than $50 \%$ of the site. Almost $100 \%$ of the deposits of the external room have disappeared, with only very small intact remains. The inner room is better preserved, with around $25 \%$ of the current surface being affected. A rigorous in situ analysis suggest that these areas are mostly undisturbed, preserving a quite intact vertical 
stratigraphy, with the potential to contribute to global debates on the origin and evolution of the Upper Palaeolithic in Mediterranean Iberia.

\section{Methods}

This section explains the methodology followed for the on-site analysis of the archaeological sequence and the subsequent selection of samples for radiocarbon dating.

The first step to clarify the archaeological sequence of the human occupations preserved in the deposits of la Cova del Moro was the systematic macroscopic description, analysis and photographic recording of the site sections (section 1 and section 2) of two trenches dug by looters.

The total core depth of sections 1 and 2 was approximately $110 \mathrm{~cm}$ and $120 \mathrm{~cm}$ respectively. Their detailed analysis revealed two main large sedimentary packages, with sediments of different colours and textures (see description in part 5: results). These two packages also included several internal levels, all of them with archaeological remains.

During the in situ analysis, the faces of the vertical sections were cleaned, from top to bottom, to minimize potential contamination when sampling the different archaeological units for radiocarbon dating. The tool used to obtain a freshly cleaned face was a metal awl, used for fine removal and to keep an accurate control of the stratigraphy. This process involved the removal of less than $3 \mathrm{~cm}$.

The sediments removed of the two identified levels were dry sieved to recover any archaeological items preserved, since they could become key finds to clarify the chronology of each level. Two superposed sieves with a 5 and a $3 \mathrm{~mm}$ mesh size were used for dry sieving to recover any potential small evidences. The loose sediments preserved at the bottom of the two looter's trenches were also sieved and appropriately labelled to recover any displaced artefacts.

The freshly cleaned faces exposed several fragments of charcoal in both stratigraphic units. Sampling was conducted in both units and site sections, and the location of each sample was accurately recorded. A wood charcoal analyst identified the plant species prior to send them to the laboratory, as explained below.

We also proceeded to the photo-documentation of the entire site to assess the state of conservation and to monitor any future human disturbance on the site, since today the site is still unprotected.

\subsection{Anthracological sampling and identification for radiocarbon dating}

Anthracological analysis should rely on systematic sampling strategies, to recover as many biotic remains as possible, for the data to be representative of the excavated sequence and 
share the problems of the other archaeological remains (Badal et al., 2003). Nevertheless, prior to an open-air excavation it is common practice to gather isolated biotic samplesbones, charcoal, seeds-for radiocarbon dating. In this case, the first step is to identify the materials sent for dating, since while the obtained chronometric dates contribute to frame the sequence in time, the information on the identified species can also offer some preliminary data on the ecology of the sequence, or help detecting potential taphonomic problems. If the materials are not previously identified, the rest of the information is lost, except for the radiocarbon date itself (Badal et al., 2012).

The sampling protocol followed at La Cova del Moro was as follows: several charcoal samples were collected along the profile, and they were identified in order to select the more suitable ones for dating, that is, taxa that, a priori, were consistent with the estimated chronology of the sequence.

On this occasion, and considering the stratigraphic packages identified, eight samples were collected.

\section{Results}

In the last few decades illicit excavations at La Cova del Moro dug two deep pits, and the sections have left exposed several stratigraphic levels. The sections have been described as "section 1" (the one closer to the entrance) and "section 2", located at the bottom of the cave (fig. 3).

Both sections share some common features, such as the presence of two well-defined and superimposed sedimentary packages:

- The top level, with fine sediment in different shades of brown, and including several sublevels composed in some instances of more or less fine gravels, and other times of sediments of different brown hues.

- A lower level, clearly differentiated from the top one, with a more granular texture, larger amounts of clasts and different shades of orange.

These sedimentary units could be used in the future as visual reference when planning and conducting the archaeological excavation.

While they share some features, they also have some specificities. The section closer to the entrance has lower levels of gravels and clasts, while they increase in section two, and more specifically in the lower package.

Through a systematic macroscopic analysis of both sections, we could distinguish between 6 and 12 different sedimentary levels and a continuous presence of archaeological remains (charcoal, bone and lithic industry) through the entire sequence.

The archaeological significance is, thus, evident. In fact, on the bottom right of section 1 there is a small pit produced by looters, deepen further into the archaeological sequence 
Table 1. La Cova del Moro recovered materials. From the Museo Arqueológico Nacional (MAN), Museu de Xàbia (MAX) and 2016 campaign

\begin{tabular}{lcccccc}
\hline & Lithic industry & Fauna & Malacofauna & Bone industry & Other & TOTAL \\
\hline MAN & 78 & 66 & - & - & - & 144 \\
MAX & 674 & 189 & 14 & - & - & 877 \\
2016 & 606 & 771 & 94 & 1 & 6 & 1,478 \\
Total & 1,358 & 1,026 & 108 & 1 & 6 & 2,499 \\
\hline
\end{tabular}

(around $30 \mathrm{~cm}$ ) and exposing various blackish levels that clearly results from strong combustion episodes. Through these observations we are confident that the archaeological levels continue below the bottom of the current pits, and thus, that more ancient archaeological levels, very likely dating back to the early Upper Palaeolithic or even before, will appear.

The archaeological remains analyzed in this paper are those recovered during the sampling campaign conducted in 2016. The lithic and bone industry and the faunal remains under study come either from the sediment detached during the cleaning of the profiles, and properly separated and labelled into two large packages, or from the dry-sieving of the soils accumulated at the bases of clandestine trenches-which were identified as clandestine soils. In this case, there is no separation between levels.

The number of remains recovered in 2016 totals 1478 items, including faunal remains and malacological remains, colouring raw materials, and lithic and bone industry. Added to those previously studied (Castaño et al., 2008), brings the total to almost 2500. With such a large number of remains we can certainly conclude that the site holds a rich deposit (table 1).

As part of this initial phase of the project, a series of samples for radiocarbon dating were collected, to more precisely confirm and clarify the Palaeolithic sequence.

\subsection{The lithic and bone industry}

The inventory of knapped stone tools recovered in 2016 includes 606 remains, all of them made of flint, either of local (Raboses type) or foreign varieties (Serreta and Mariola types, located about $60 \mathrm{~km}$ from the site). Most of the remains are flakes, though blades are also present. Cores and core conditioning products (CCP) resulting from lithic reduction are well represented. The number of retouched tools recovered is very low, with only 12 tools, representing $2 \%$ of the total (table 2 ).

The list of retouched tools includes a certain balance between the represented types (end-scrapers, backed bladelets/points, side-retouched pieces, burins and notches) Unfortunately, no conclusive diagnostic tools pointing to a specific time period have been recovered. This justifies the need to take samples for radiocarbon dating to clarify the 
Table 2. Lithic and osseous industry and colouring raw materials recovered in 2016 campaign. Materials from Sections 1 and 2 and Clandestine Soils

\begin{tabular}{lrrrrrr}
\hline & CS & S2 Inf & S2 Sup & S1 Inf & S1 Sup & Total \\
\hline Flake & 440 & 21 & 35 & 8 & 10 & 514 \\
Blade/Bladelet & 43 & 3 & 2 & - & 1 & 49 \\
Core & 13 & 5 & 4 & - & - & 22 \\
CCP & 9 & - & - & - & - & 9 \\
Stone tools & 10 & 2 & - & - & - & 12 \\
Total & 515 & 31 & 41 & 8 & 11 & 606 \\
\hline Other (Ochre) & 4 & 1 & 1 & - & - & 6 \\
Osseous Industry & 1 & - & - & - & - & 1 \\
\hline
\end{tabular}

Table 3. Stone tools from 2016 campaign

\begin{tabular}{lcc}
\hline & CS & S2 Inf \\
\hline End-Scraper & 3 & - \\
B. Bladelet & 2 & - \\
Side Retouch & 2 & - \\
Burin & 1 & 1 \\
Notch & 2 & 1 \\
Total & 10 & 2 \\
\hline
\end{tabular}

sequence. Nevertheless, the small size of two of the scrapers and the presence of a fine backed bladelet point towards the end of the Palaeolithic (fig. 5 and table 3). Only two pieces (a burin and a notch) come from the lower level and were recovered during the cleaning process, while the others come from the clandestine soils.

Regarding the bone tools industry, only a small fragment of a piece of worked bone has been recovered. The fragment unearthed shows traces of manufacture (slight reduction) at one end, probably the proximal end (fig. 5). With certain reservations, considering the small dimensions of this piece, the resulting shape seems close to that of the Gravettian and Solutrean pieces of the neighboring Cova de les Cendres (Villaverde y Román, 2004), located only around 2'3 km away.

\subsection{Faunal assemblage}

The faunal assemblage here presented comes also from the 3 locations previously described: section 1 , section 2 and clandestine soils. As previously mentioned, none of the materials result from a proper and methodical archaeological excavation. The materials recovered 


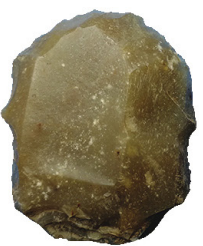

1

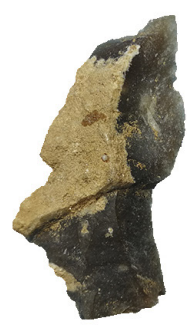

5

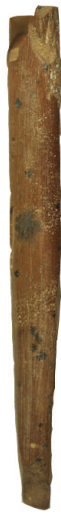

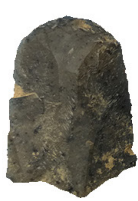

2

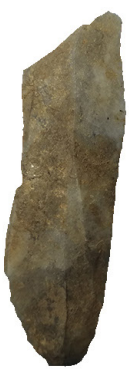

6

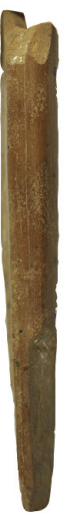

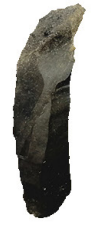

3

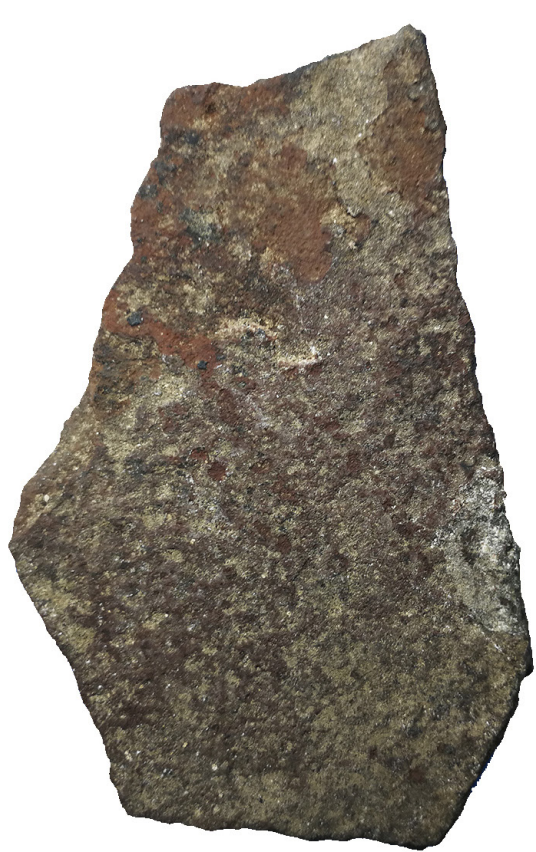

8

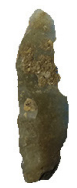

4

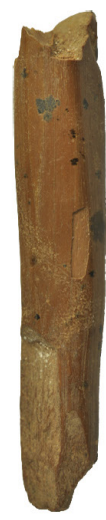

\section{7}

Figure 5. L Lithic and osseous industry from 2016 campaign. End-scrapers (1-2), backed bladelets (3-4), side-retouched pieces (5-6), point fragment (7), slab with red pigment (8).

from the cleaning of the sections are divided into the upper and lower packages, but those from the clandestine soils are the result of illicit incursions mixing materials and levels. That has to be borne in mind when analyzing the results and drawing conclusions, since the bone remains could belong to both Upper Palaeolithic and Holocene moments. The sample of the "clandestine soils" contains most of the faunal remains under study (table 4). 
Table 4. Faunal and malacological remains from 2016 campaign

\begin{tabular}{|c|c|c|c|c|c|}
\hline & S1 Sup & S2 Sup & S1 Inf & S2 Inf & CS \\
\hline Cervus elaphus & & 2 & 3 & 2 & 13 \\
\hline Caprinae & 1 & 2 & 2 & 2 & 60 \\
\hline Equidae & & & & 2 & 13 \\
\hline Leporidae & 17 & 53 & 39 & 42 & 409 \\
\hline Canidae & & & & & 1 \\
\hline Vulpes & & 1 & & 1 & 3 \\
\hline Lynx sp. & & & 1 & 1 & \\
\hline Carnivora & & 1 & & & \\
\hline Birds & 1 & & & & 5 \\
\hline Fauna indet. & 9 & 23 & 23 & 29 & 259 \\
\hline Malacofauna & 1 & 3 & 2 & 4 & 94 \\
\hline \multirow[t]{2}{*}{ Microfauna } & & & & & 8 \\
\hline & 29 & 85 & 70 & 83 & 865 \\
\hline
\end{tabular}

\subsubsection{Taxonomy}

The taxonomic spectrum is mostly composed of leporid remains (fig. 6 and table 5). Species of medium-sized ungulates such as Cervus and goats, and large-sized species such as Equus sp. have been also identified. Additionally, although in lower quantities, remains of carnivores such as lynx, fox and another species of canines to be determined have been recorded (fig. 7 and table 4). The materials reviewed also include bird remains, microfauna and both terrestrial and marine malacofauna.

Table 5. Leporidae NISP from Clandestine Soils (anatomical elements)

\begin{tabular}{lrr}
\hline & NISP \\
\hline Da & 21 \\
Cr & Mx & 8 \\
Hem & 7 & 27 \\
V & 16 \\
Es & 2 \\
H & 16 \\
R & 22 \\
U & 25 \\
Cx & 25 \\
F & 15 \\
T & 37 \\
Ca & 40 \\
Mtp & 37 \\
Fa1 & 19 \\
In & 33 \\
& 4 \\
\hline
\end{tabular}



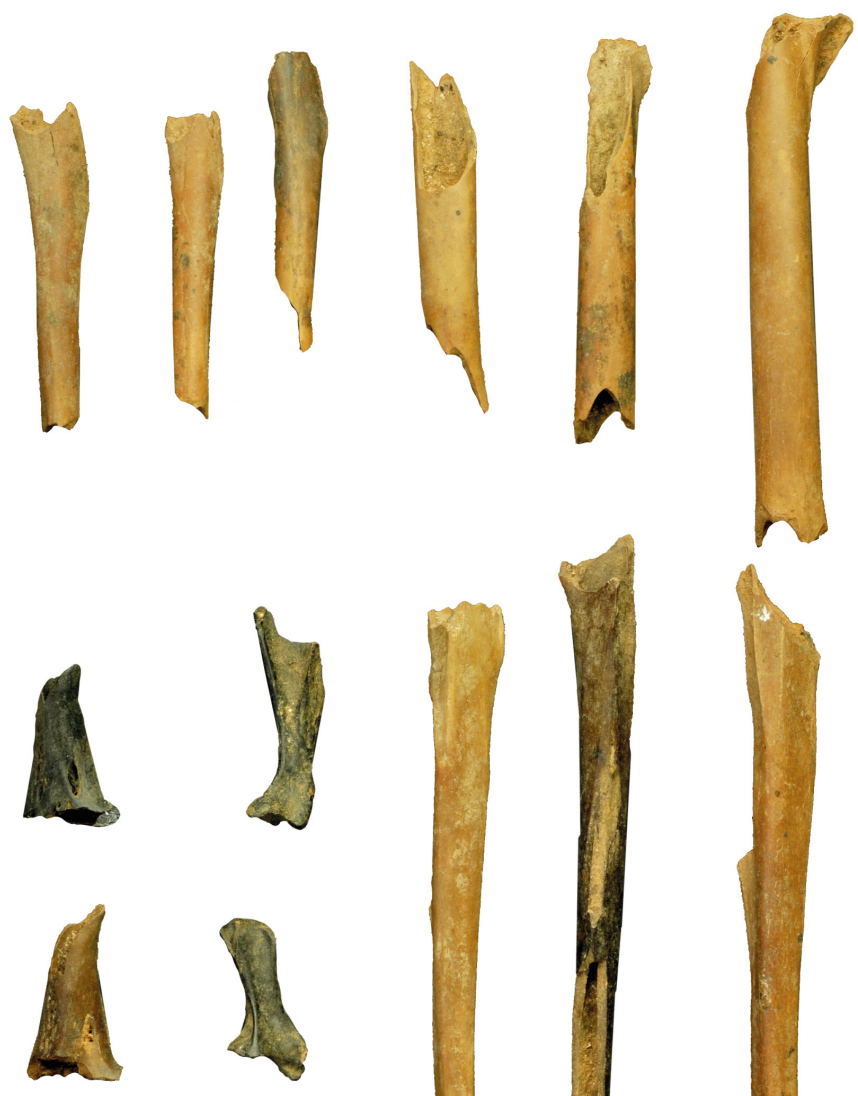

$1 \mathrm{~cm}$
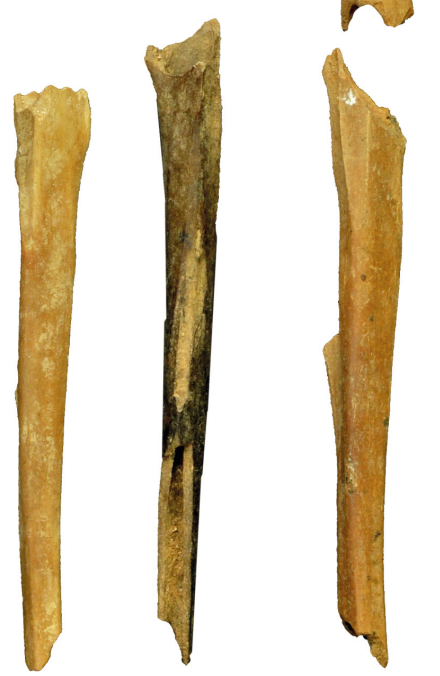

Figure 6. Leoporiade remains (humerus, femur, tibia, jaw and scapula) with fresh fractures and heat alterations.

In relation to the caprine animal remains, most of the bones correspond to domestic species, mostly to Capra hircus, except for one piece that could be from Ovis aries. Forty eight of the bones belong to very young individuals and, as such, they cannot be assigned to any of the two species. Thus, they have been classified as Caprinae.

Among the fox remains, two mandibular fragments have been found that seem to belong to a very young individual-even though they have been found in different areasas well as a complete metacarpus. As for the other carnivores, lynx bones-a fragmented coxal bone and a complete second phalanx - a first phalanx of Canis sp., and a metapodium classified as Carnivora have been identified.

Overall, the number of remains recovered for each of the taxa is too low to assess their anatomical representation, except for Leporidae. In this case, all the anatomical groups are 


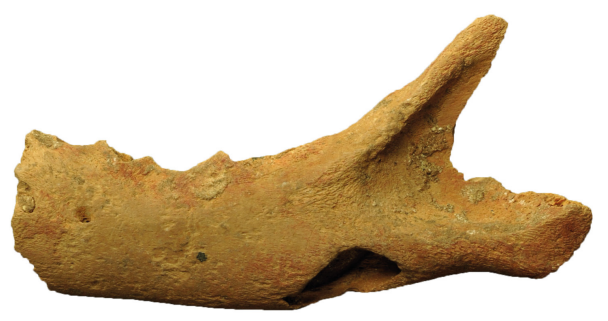

Figure 7. Carnivora remains: Vulpes jaw, first phalange $1 \mathrm{~cm}$

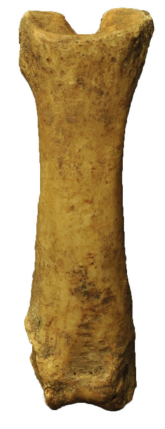
and metacarpus; and Canis sp. first phalange.

represented, although the axial zone and the extremities, as well as the elements of the carpus and tarsus are underrepresented or even absent (table 5). This may be due to the recovery strategy, since the bones come from disturbed deposits that were partially sieved.

\subsubsection{Tafonomy}

Two different patterns are observed. On the one hand, the remains of Capra hircus / Ovis aries / Caprinae are complete, with no modifications by any type of agent. On the other hand, the bones of the other taxa-Cervus and Equus-are mostly fragmented, especially for deer. The fractures are old and appear to have been made fresh. In the "Clandestine soils", we also find a medial diaphyseal fragment of deer metacarpus with incisions and a notch by percussion (fig. 8B). Likewise, medium-sized diaphysis fragments show the same pattern of fresh fracture, 12 of them with lithic cut marks-those recovered as part of the clandestine soils-and even three percussion flakes (fig. 8A). Most of the remains of Leporidae are fragmented, although some bones are complete. The fractures show morphotypes of complete cylinders of diaphysis of bones such as humerus, femur or tibia, as well as fragments of joints (fig. 6). Complete bones correspond mostly to young individuals. 

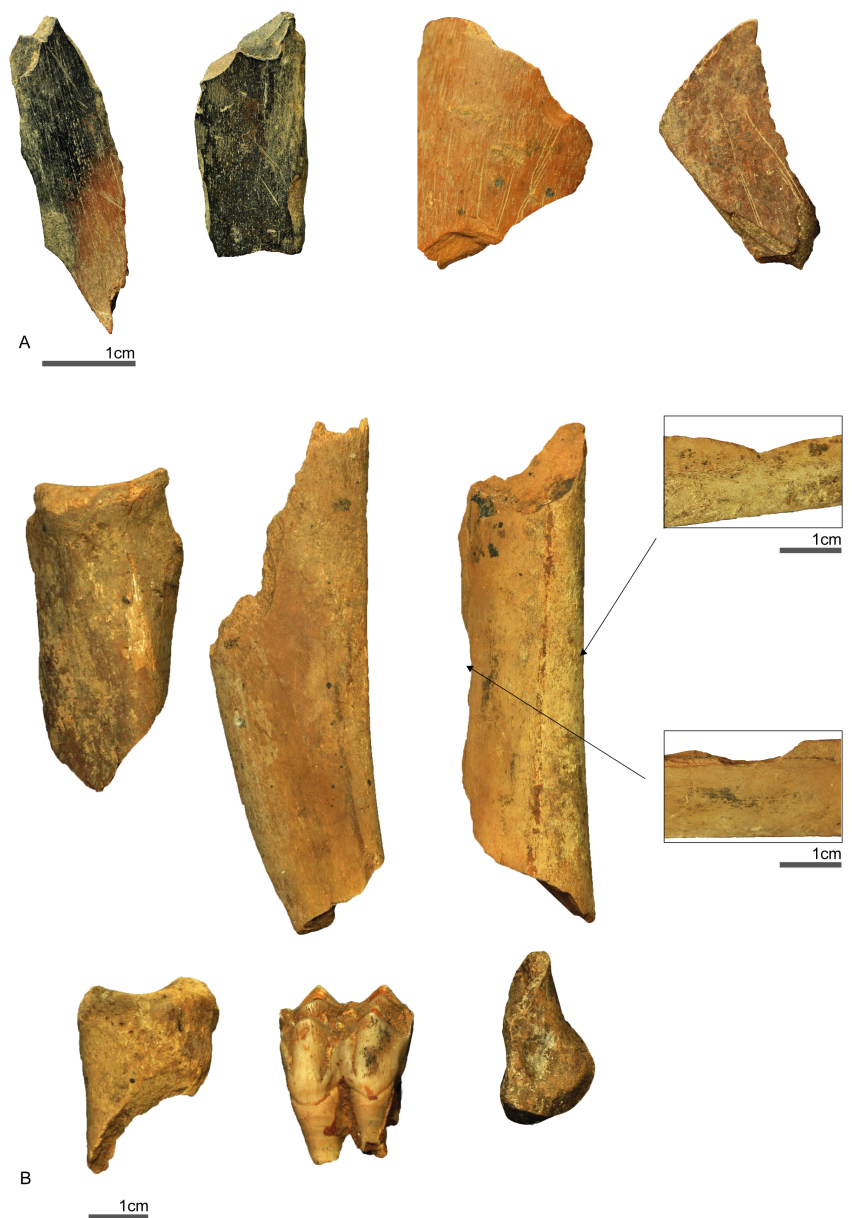

Figure 8. A. Cut marks and heat alterations in medium size elements. B. Cervus elaphus remains: long bones and phalanges with fresh fractures and metacarpus with direct percussion marks.

Heat alterations have been also identified, most of them with burning effects, with black staining affecting the entire bone surface. Some fragments were calcined (fig. 8). The effects of fire have affected most of the taxa-Cervus, Leporidae, Carnivora-except for the remains of Caprinae.

\subsubsection{Concluding remarks to the faunal assemblage}

Overall, despite the possible mixing of strata in the samples under study, two large assemblages have been distinguished. On the one side, remains of Caprina, including complete 
and unmodified remains which mostly correspond to young and small individuals. These remains are likely related to domestic species associated to the more recent Holocene occupations involving cattle rising activities. It should be noted that fragments of prehistoric pottery were identified along the outside of the site, which could be connected to these occupations. In addition, very close to La Cova del Moro we find La Cova de les Cendres, with a long ceramic sequence ranging from the early Neolithic to the Bronze Age, and with clear indicators of the use of the cave as livestock fold (Bernabeu, 1989, Bernabeu and Molina (ed), 2006). This could suggest an analogous use of this cave in more recent prehistoric times.

On the other side, the assemblage of Cervus, Leporidae and medium size remains could be related to Palaeolithic human occupations. These remains show old fractures, with lithic marks and signs of fresh and direct fractures, probably butchery marks produced in the process of removing animal tissues (meat and marrow). In addition, both the taxonomic spectrum and the patterns of faunal processing are similar to those observed at the neighboring Cova de les Cendres (Pérez Ripoll 2005/2006, Sanchis et al. 2016, Real 2017). However, it is worth stressing that when referring to leporidae, young individuals and some of the fragmented adult remains could perfectly fit in more recent times as well.

Equus elements could also belong to the Palaeolithic occupations, though the number of remains is too low to make an accurate assessment.

Finally, the remains of carnivores could be either related to the Palaeolithic or the more recent prehistoric occupations. Nevertheless, the fact that a good sample of bones and animal bone artefacts are made of these species-linx, fox, canids-in the taxonomic list of other Upper Palaeolithic sites (Real 2017, Real et al., 2017, Villaverde et al., 2012), suggests that they could be associated with the Palaeolithic levels.

\section{Anthracology}

Three different taxa have been identified through the analysis of the 8 fragments of archaeological charcoal collected at La Cova del Moro: Pinus tp. nigra, Fabaceae and Juniperus sp. The age of two of the fragments of pine places them in the Gravettian, while two other fragments, pine and juniper, have been dated to the lower / middle Magdalenian (table 6).

These taxa are characteristic of most of the anthracological sequences available for the Upper Paleolithic in this region (Badal and Carrión, 2001, Badal et al., 2012). The nearby Cova de les Cendres has provided several dates on fragments of Pinus nigra dating them between the Gravettian and the Magdalenian. These results show that these species had a prominent role in Mediterranean plant formations during the Pleniglacial and Tardiglacial (Badal, 2006, Badal and Martínez Varea, 2017). The trinomial Pinus nigra-Juniperus-Fabaceae is also detected in the Aurignacian levels of La Cova Foradada in Xàbia (Badal, 1997). 
The Gravettian levels at La Cova de les Cendres are, in fact, dominated by Pinus nigra formations, although fabaceae and junipers have also an extensive presence (Badal and Carrión, 2001). This image is quite homogeneous throughout the Upper Paleolithic of the cave, although between the evolved Solutrean and the middle Magdalenian-20500-17600 cal BP-a regression of pines, and an expansion of fabaceous-juniper formations has been identified. These taxa are more characteristic of open spaces, with more open woodlands than in the other parts of the sequence and do also point to a drier period (Badal and Carrión, 2001).

The fragment of Juniperus from La Cova del Moro dated to the lower Magdalenian will fit in this period. A tardiglacial phase dominated by Juniperus has been detected in several archaeological deposits of the region, such as the lower/middle Magdalenian levels of La Cova de les Cendres, where at least several juniper species have been identified based on the analysis of the carpological record (Badal and Martínez Varea, 2017), or the ancient Epipaleolithic levels of several sites of Alicante, such as Cova Bolumini (Beniarbeig) (Badal, 1995), Coves de Santa Maira (Castell de Castells) (Aura et al., 2005) or Tossal de la Roca (Vall d'Alcalà) (Uzquiano, 1990).

\section{The radiocarbon dates}

One of the primary aims of this first field campaign was to obtain a series of dates to clarify the sequence, to confirm if the site had a single or a long continuing occupation over the upper Palaeolithic and to assess the degree of disturbance of the archaeological sequence considering the number of illicit excavations conducted at the site. While 8 charcoal samples were collected and identified by a charcoal analyst, only 4 of them (2 per section) were sent for radiocarbon dating. We selected one sample per each of the two large sedimentary packages identified in both sections (top level and bottom level). The idea to send samples collected in each of the packages of each profile, which look similar from the compositional point of view, was to check if despite the significant differences in depth between both profiles, the upper and the lower packages identified in each of them were contemporaries.

The samples sent for dating included 3 fragments of Pinus nigra charcoal and one of Juniperus. The latter was collected from the upper level of section 2 (fig. 9 and table 6).

The dates obtained confirm that the site preserves a long sequence of Upper Palaeolithic human occupations, with at least some levels dating to the Gravettian and the lower/middle Magdalenian. If we add to that the identification of a fragment of a laurel leaf point characteristic of the Solutrean, we have an almost complete sequence of the Upper Palaeolithic.

As it will be later discussed, these levels are not strange in the territory surrounding this site, especially considering the presence of La Cova de les Cendres around $2 \mathrm{~km}$ away 


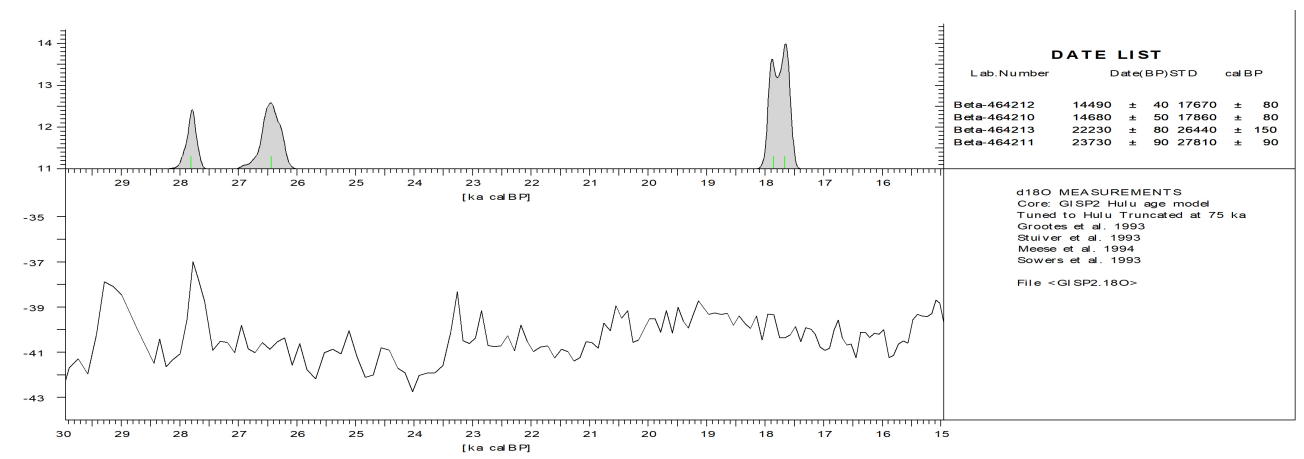

Figure 9. La Cova del Moro calibration curve (INTCAL13) obtained with CalPal (Weninger and Joris, 2008).

Table 6. La Cova del Moro radiocarbon dates

\begin{tabular}{lrccccc}
\hline Sample & Level & BP & $\mathbf{I}$ & cal. BP & Reference & Taxa \\
\hline M1 & S2 Sup & 14680 & 50 & $18030-17685$ & Beta-464210 & Juniperus \\
M4 & S2 Inf & 23730 & 90 & $27984-27625$ & Beta-464211 & Pinus nigra \\
M6 & S1 Sup & 14490 & 40 & $17863-17495$ & Beta-464212 & Pinus nigra \\
M7 & S1 Inf & 22230 & 80 & $26754-26150$ & Beta-464213 & Pinus nigra \\
\hline
\end{tabular}

from la Cova del Moro. This site preserves one of the most complete sequences for the Upper Palaeolithic in Mediterranean Iberia (Villaverde et al., 2010 and 2017).

Besides confirming that La Cova del Moro has a long Upper Palaeolithic sequence, these dates are also useful to understand the process of formation of the deposits, which show a significant dip towards the deeper part of the cavity. Thus, while both looters trenches have different depths, their top and bottom packages have similar dates, thus confirming these sedimentary patterns.

Further studies will contribute to understand if this dip is due to materials redeposited in the inner parts of the cave coming from the external parts of it-since the external part is located at a significantly higher level—or if on the contrary there were human occupations also in this deeper part, or even if it is just a passage way giving access to another potentially larger cavity today filled with sediments.

\section{Conclusions}

The results of our 2016 assessment of the potential, the archaeological sequence and the impact of illicit excavations at La Cova del Moro site, in conjunction with the data 
obtained from previous analysis of the materials kept at the Museo Arqueológico Nacional and the Museu de Xàbia, provides a first picture of the potential of this site to contribute new data and knowledge to advance on the characterization of the Upper Palaeolithic in Mediterranean Iberia.

While the project is still in a preliminary stage, this initial data-gathering provides a glimpse of the archaeological richness of the deposits and confirms human occupations at this site at least since the end of the Gravettian and up until the middle Magdalenian. Moreover, considering the sedimentary thickness visible above the Magdalenian dates and very possibly below the Gravettian levels, we are confident that the Palaeolithic occupations at this site will expand beyond the periods identified so far.

Thus, we believe that we are in good conditions to state that, despite the significant damages caused by illicit excavations and urban developments, la Cova del Moro site can be still considered a first-class site that will surely yield new data to advance knowledge on Upper Palaeolithic archaeology. In addition, the site is located in one of the areas with the highest concentration of Upper Palaeolithic sites in Iberia, such as the North of Alicante and the South of Valencia (fig. 10), thus offering an ideal setting for intra-site comparative analysis.

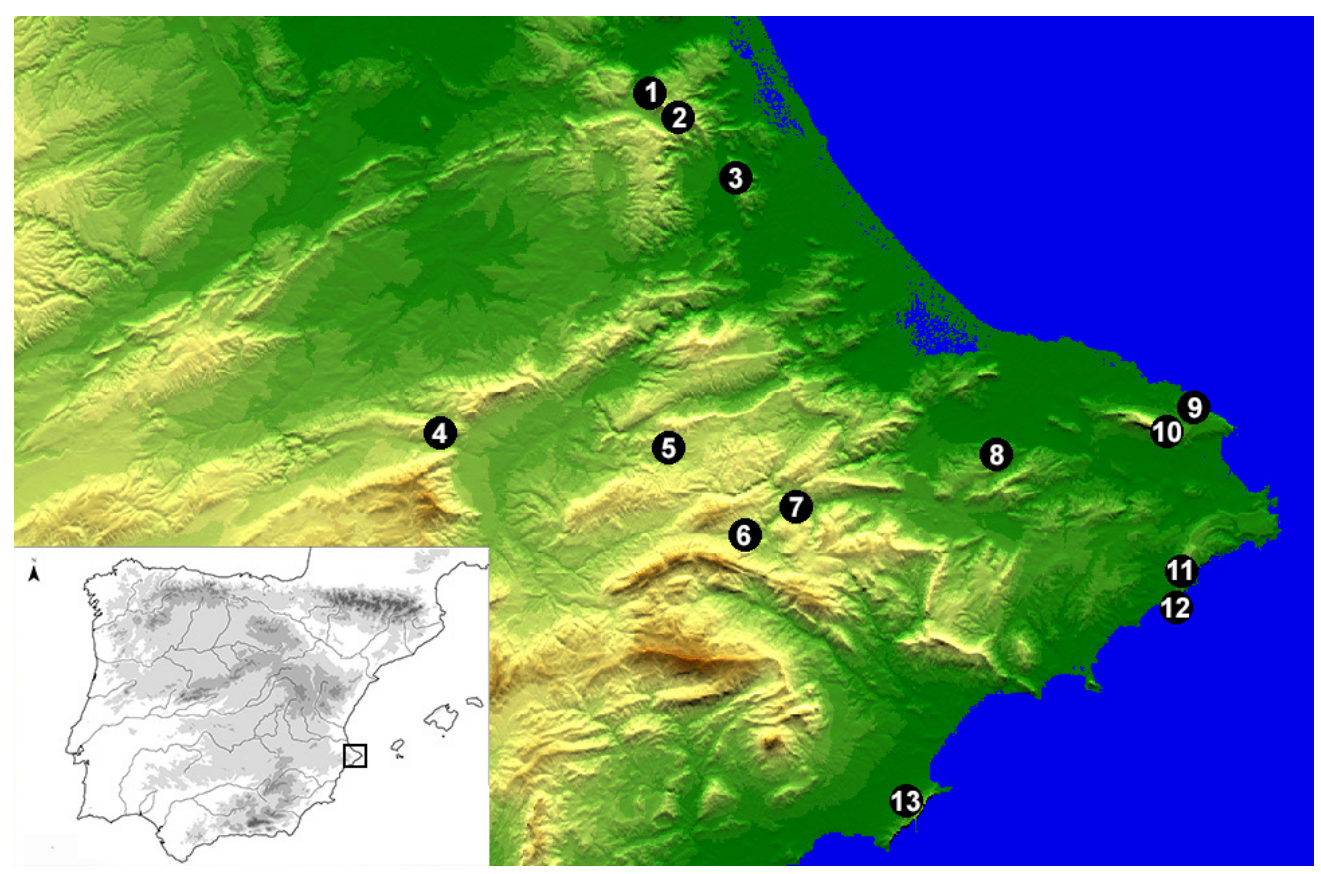

Figure 10. Location of sites cited in the text: 1 Cova de les Malladetes, 2 Cova del Parpalló, 3 Cova de les Meravelles, 4 Cova Beneito, 5 Tossal de la Roca, 6 Coves de Santa Maira, 7 Casa dels Moliners, 8 Cova del Comte, 9 Cova Foradada, 10 Cova Ampla del Montgó, 11 Cova del Moro, 12 Cova de les Cendres, 13 Cova de la Barriada. 
Within a $25 \mathrm{~km}$ radius around La Cova del Moro, we find sites as important as la Cova de les Cendres, with an almost complete sequence from the Aurignacian to the Magdalenian (Villaverde et al., 2017, Villaverde et al., 2010); Cova del Montgó (Xàbia) with Solutrean levels (Aparicio et al., 1979); Cova Foradada (Xàbia) with Aurignacian occupations (Casabó, 2001); Cova del Comte (Pedreguer) with Palaeolithic art and Gravettian occupations (Casabó et al., 2016) or Cova de la Barriada (Bernidorm) with various Gravettian levels (Fernandez López de Pablo et al., 2014). And if we extend this radius to $50 \mathrm{~km}$, we can add other sites with important paleolithic sequences such as Cova del Parpalló (Gandía) (Pericot, 1942), Cova de les Malladetes (Barx) (Fortea and Jordà, 1976), Cova de les Meravelles (Gandía) (Villaverde et al., 2009), Coves de Santa Maira (Aura et al., 2001) or Tossal de la Roca (Cacho et al., 1995), to name a few of the most well-known sites.

With this preliminary approach, in addition to the study of the lithic assemblage and the first radiocarbon dates obtained for this site, we have been able to conduct the first zooarchaeological and anthracological evaluation. In both cases, the data back the presence of several paleolithic levels and suggest that the preservation of the stratigraphy may be good where the deposits have remained untouched.

While waiting for the results of a complete anthracological analysis, this preliminary identification shows a presence of woody taxa consistent with the information available from other sites in the region for the same time period. In the absence of quantitative results, we cannot yet draw more meaningful conclusions, but the presence of some of the ecological markers typical of the periods under study is relevant, as explained in the corresponding section. In fact, the three taxa identified at La Cova del Moro are the same as those documented in the Paleolithic levels of Cova de les Cendres or Cova Foradada, to name some of the closest sites in the region.

The faunal analysis gives some preliminary clues on the different types of human occupations and animal use strategies at the site in prehistoric times. On the one hand, there is a certain number of goat remains most likely corresponding to domestic animals, and thus pointing toward Neolithic times. On the other hand, the remains of deer, horse and some carnivores and their patterns of fracture match those identified in nearby Palaeolithic sites, so they most probably date to the Upper Palaeolithic.

As previously mentioned, the access to the second room is through a small descending passage. The arrival of domestic taxa to this part of the cave could well be explained in relation to the use of the external room as a fold, which may instigate the use of the internal room, of difficult access, as a place where to throw either the carcasses of the dead fauna or the bones of the consumed animals, in Holocene times. The next step would be to associate these domestic remains to a particular period of time. In the Museu de Xàbia, several archaeological remains from this site speak of a possible use of the cave during the final Neolithic, maybe as a burial cave. They include a fragment of prehistoric pottery and the end of a copper awl. Nevertheless, the number of postpaleolithic remains is low. If we can finally date these postpalaeolithic occupations, we could have more chances to determine how the animal remains arrived to the internal cave. 


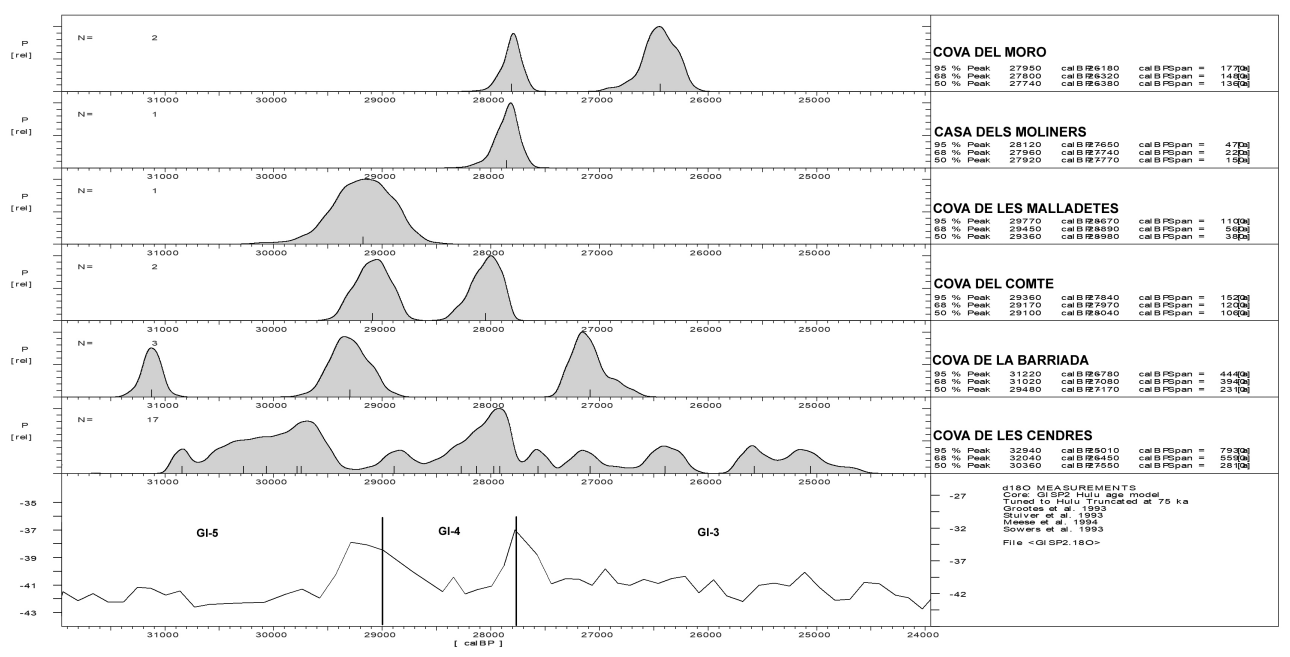

Figure 11. Dates from Gravettian sites in Valencian Country. Calibration curve (INTCAL13) obtained with CalPal (Weninger and Joris, 2008).

On the other hand, the lithic assemblage recovered so far doesn't contain many diagnostic lithic elements to be used as cultural markers. However, a fragment of a Solutrean laurel leaf point confirms that people inhabited or visited this cave in that period. Among the other lithic tools, two small scrapers and a backed bladelet could point towards the Magdalenian.

On the other hand, radiocarbon dates confirm, at least, the presence of Gravettian and Lower / Middle Magdalenian levels. For a long time in the Valencian Country the Gravettian was represented in a limited number of sites, such as Cova del Parpalló, Cova de les Malladetes (Fortea and Jordà, 1976, Miralles, 1982) and Cova Beneito (Iturbe et al., 1993). But in the last decade the number of archaeological sequences including archaeological levels dating to this period has substantially increased. Particularly significant are the levels at La Cova de les Cendres, covering the entire Gravettian sequence and providing the main cultural, economic and paleoenvironmental data for this period in Iberia (Villaverde and Román, 2004, Villaverde et al., 2017). Other new sites making substantial contributions and complementing the data from Cendres are la Cova de la Barriada (Fernandez Lopez de Pablo et al., 2014), Cova del Comte (Casabó et al., 2016) or the open-air site of Casa dels Moliners-Castell de Castells-(Miret et al., 2016) (fig. 11). Considering the good preservation of organic materials at la Cova del Moro, we are confident that the site will contribute significant data to make progress on further Upper Palaeolithic research in Iberia.

The other two radiocarbon dates point to different human occupation located somewhere between the lower and the middle Magdalenian. This period is quite poorly defined 
in Mediterranean Iberia, with just a few evidences from Cova de les Cendres and Cova del Parpalló, still under study. So if future excavations confirm the presence of a good assemblage of archaeological remains related to this period, the archaeological significance of this site will notably increase. Human occupations, that if confirmed in future excavations, will become one of the first evidence for that period in Mediterranean Iberia, and the first to offer a comprehensive study in this area.

In conclusion, the Palaeolithic sequence preserved at La Cova del Moro is comparable to that of other major Palaeolithic sites of Mediterranean Iberia. The analysis conducted so far suggest that the deposits still in place after the illicit excavations are sufficiently well preserved and have the potential to provide significant data to advance on the definition of the sequence, the technologies and the economies of Palaeolithic societies in Mediterranean Iberia. The repeated occupation of the same cave throughout the Upper Palaeolithic is not unique to this site, but is not that frequent in this region, so the few

places known so far with such a sequence are certainly key to build a more global picture of the period in this region.

The huge potential of this site to contribute to global debates has been underestimated for a century, bearing a very low or no interest to archaeologists and even less to the administration. Despite continuous warnings informing on illicit excavations and others disturbances produced by urban developments in the area, the site remains unprotected.

It is our hope that this paper will serve as a starting point not only to advance on the scientific understanding of the Palaeolithic sequence of the site and to evaluate its potential role in redefining the ways of life of the human groups inhabiting these lands during the Upper Palaeolithic, but also to draw the attention of the authorities to the dramatic situation of the site and persuade them to take the appropriate measures to urgently protect it.

\section{Acknowledgements}

Much of this work was funded by El Poble Nou de Benitatxell city council. We thank their interest and support to advance knowledge on La Cova del Moro site and the prehistory of the region. This research is also partially involved in the project HAR2016-80693-P. 


\section{References}

APARICIO, J., SANCHO, A. and SAN VALERO, J., 1979, Materiales neolíticos de la Cova del Forat del Aire Calent y de la Cova del Llop Gandía, Valencia, Universidad de Valencia, Serie Arqueológica 6, València.

AURA, J.E., CARRIÓN MARCO, Y., GARCÍA PUCHOL, O., JARDÓN, P., JORDÁ, J. F., MOLINA, Ll., MORALES, J. V., PASCUAL, J. Ll., PÉREZ JORDÁ, G., PÉREZ RIPOLL, M., RODRIGO, M. J. and VERDASCO, C., 2006, Epipaleolítico-Mesolítico en las comarcas centrales valencianas, in A. ALDAY (coord.), El Mesolítico de muescas y denticulados en la cuenca del Ebro y el litoral mediterráneo ibérico, Memorias de Yacimientos Alaveses 11, 65-118.

AURA, E., CARRIÓN, Y., ESTRELLES, E. and PÉREZ JORDÁ, G., 2005, Plant economy of hunter-gatherer groups at the end of the last Ice Age. plant macroremains from the cave of Santa Maira Alacant, Spain ca. 12000-9000 BP, Vegetation History and Archaeobotany 14 (4), 542-550.

BADAL, E., 1995, La vegetación carbonizada. Resultados antracológicos del País valenciano, in El cuaternario en el País Valenciano, Universitat de València, València, 217-226.

BADAL, E., 1997, El paisatge vegetal de La Marina, a partir dels carbons prehistòrics, Aguaits. Revista d'Investigació i Assaig, 3-14, Institut d'Estudis Comarcals de La Marina Alta, 23-37.

BADAL, E., 2006, Carbones y cenizas, ¿qué nos cuentan del pasado?, en J. S. CARRIÓN, S. FERNÁNDEZ and N. FUENTES (coords.), Paleoambientes y cambio climático, Ed. Fundación Séneca, Murcia, 103-116.

BADAL, E. and CARRIÓN, Y., 2001, Del glaciar al interglaciar. los paisajes vegetales a partir de los restos carbonizados en las cuevas de Alicante, in V. VILLAVERDE (ed.), De Neandertales a Cromañones. El inicio del poblamiento humano en tierras valencianas, Universitat de València, València, 21-40.
BADAL, E. and MARTÍNEZ VAREA, C. Ma., 2017, Different parts of the same plants. Charcoals and seeds from Cova de les Cendres Alicante, Spain, Quaternary International 2017, http.//dx.doi. org/10.1016/j.quaint.2016.12.020.

BADAL, E., CARRIÓN, Y., RIVERA, D. and UZQUIANO, P., 2003, La arqueobotánica en cuevas y abrigos. objetivos y métodos de muestreo, in R. BUXÓ and R. PIQUÉ (dirs.), La recogida de muestras en arqueobotánica. objetivos y propuestas metodológicas. La gestión de los recursos vegetales y la transformación del paleopaisaje en el Mediterráneo occidental, Museu d'Arqueologia de Catalunya, Barcelona, 19-29.

BADAL, E., CARRIÓN, Y., FIGUEIRAL, I. and RODRÍGUEZ-ARIZA, $M^{a}$. O., 2012, Pinares y enebrales. El paisaje del Solutrense en Iberia, Espacio Tiempo y Forma. Serie I, Prehistoria y Arqueología, Nueva época, $\mathrm{n}^{\circ}$ 5, De punta a punta. El Solutrense en los albores del siglo XXI. Congreso Internacional El Solutrense - Centenario de las excavaciones en La Cueva del Ambrosio Vélez-Blanco, Almería, España, del 25 al 28 de junio de 2012. Madrid, 263-276.

BERNABEU, J., 1989, La Tradición Cultural de las cerámicas impresas en la zona oriental de la Península Ibérica, Trabajos Varios del SIP 86, Diputació de València, València.

BERNABEU, J. and MOLINA, Ll. (eds.), 2006, La Cova de les Cendres Moraira-Teulada, Alicante, Museo Arqueológico de Alicante MARQ, Serie Mayor 6, Alicante.

BOLUFER, J., 2005, El Patrimoni Arqueològic del Poble Nou de Benitatxell, Xàbiga 9, 25-46.

CACHO, C., FUMANAL, M. P., LÓPEZ, J. A, PÉREZ-RIPOLL, M., MARTÍNEZ-VALLE, R., UZQUIANO, P., ARNANZ, A., SÁNCHEZ, A., SEVILLA, P., MORALES, A., ROSSELLÓ, E., GARRALDA, M. D. and GARCIA-CARRILLO, M., 1995, El Tossal de la Roca (Vall d'Alcalà, Alicante). Reconstrucción paleoambiental y cultural de la transición del Tardiglaciar al 
Holoceno inicial, Recerques del Museu d'Alcoi 4, $11-101$.

CASABÓ, J., 1990, Avance al estudio de nuevos yacimientos paleolíticos y epipaleolíticos en el NE de Alicante, in Actes del III Congrés d'Estudis de la Marina Alta, Institut de Cultura Juan Gil-Albert, Alacant, 13-29.

CASABÓ, J., 2001, Cova Foradada Xàbia, Alacant, in V. VILLAVERDE (ed.), De Neandertales a Cromañones. El inicio del poblamiento humano en tierras valencianas. Universitat de València, València, 407-410.

CASABÓ, J., BORONAT, J. DE D., CARRIÓN MARCO, Y., ESQUEMBRE, M. A., GUILLEM, P. M., MARTÍNEZ-VALLE, R., SOLER, B., COSTA, P. and BOLUFER, J., 2016, New evidence of Palaeolithic rock art at the Cova del Comte Pedreguer, Spain. results of the first surveys, Quaternary International 432, 25-40, http.//dx.doi. org/10.1016/j.quaint.2015.12.061.

CASTAÑO, A., ROMÁN, D. and SANCHIS, A., 2008, El jaciment Paleolític de la Cova del Moro Benitatxell, La Marina Alta, Archivo de Prehistoria Levantina XXVII, 25-49.

FERNÁNDEZ-LÓPEZ DE PABLO, J., BADAL, E., FERRER GARCÍA, C., MARTÍNEZ-ORTÍ, A. and SANCHIS SERRA, A., 2014, Land snails as a diet diversification proxy during the early upper palaeolithic in Europe, PLos One 9(8), https.//doi. org/10.1371/journal.pone.0104898.

FLETCHER, D., 1945, Restos arqueológicos valencianos de la colección de D. Juan Vilanova y Piera en el Museo Antropológico Nacional, Archivo de Prehistoria Levantina II, 343-348.

FORTEA, J. and JORDÀ, F., 1976, La Cueva de les Mallaetes y los problemas del Paleolítico superior del Mediterráneo español, Zephyrus XXVI-XXVII, 129-166.

ITURBE, G., FUMANAL, M. P., CARRIÓN, J. S., CORTELL, E., MARTÍNEZ-VALLE, R., GUILLEM, P. M., GARRALDA, M. D. and VANDERMEERSCH, B., 1993, Cova Beneito Muro, Alicante. una perspectiva interdisciplinar, Recerques del Museu d'Alcoi 2, 23-88.
MIRALLES, J. L., 1982, El Gravetiense en el País Valenciano, Saguntum Plav. 17, 45-63.

MIRET,C., CARRIÓN, Y., HORTELANO, L., JARDÓN, P., RUIZ, J. M. and DE WIT, H., 2016 , Casa dels Moliners Castell de Castells, Alacant. Un jaciment a l'aire lliure del Paleolític superior en el Pla de Petraco, Archivo de Prehistoria Levantina XXXI, 27-60.

PÉREZ RIPOLL, M. 2005/2006, Caracterización de las fracturas antrópicas y sus tipologías en huesos de conejo procedentes de los niveles gravetienses de la Cova de les Cendres, Alicante, Munibe 57(1), 239-254.

PERICOT, Ll., 1942, La Cueva del Parpalló (Gandía), Consejo Superior de Investigaciones Científicas, Instituto Diego Velázquez.

PRIETO, S., 2017, La colección arqueológica de Juan Vilanova y Piera, Boletín del Museo Arqueológico Nacional 36, 35-54.

REAL, C., 2017, Estudio arqueozoológico y tafonómico del Magdaleniense de la Cova de les Cendres (TeuladaMoraira, Alicante), PhD Thesis, Universitat de València, València.

REAL, C., MORALES-PÉREZ, J. V., AURA, J. E. and VILLAVERDE, V., 2017, Aprovechamiento del lince por los grupos humanos del Tardiglaciar. El caso de la Cova de les Cendres y Les Coves de Santa Maira, in A. SANCHIS and J. L. PASCUAL (eds.), Interaccions entre felins i humans. III jornades d'arqueozoologia, Museu de Prehistòria de València, 161-188.

SANCHIS, A., REAL, C. PÉREZ RIPOLL, M. and VILLAVERDE, V., 2016, El conejo en la subsistencia humana del Paleolítico superior inicial en la zona central del Mediterráneo ibérico, in Ll. LLOVERAS, C. RISSECH, J. NADAL and J. M. FULLOLA (eds), What bones tell us / El que ens expliquen els ossos, Monografies del SERP 12, Universitat de Barcelona, Barcelona, 145-156.

UZQUIANO, P., 1990, Analyse anthracologique du Tossal de la Roca Paleolithique Supérieur FinalEpipaleolithique, province d'Alicante, Espagne, 1st European Conference on wood and archaeology, PACT 22, 209-217. 
VILANOVA I PIERA, J., 1889, Discursos leídos en la Real Academia de la Historia en la recepción pública del Dr. Juan Vilanova y Piera el día 29 de junio de 1889, Imprenta de A. Pérez Dubrull, Madrid.

VILANOVA I PIERA, J. and RADA, J., 1892, Geología y Protohistoria ibéricas, in A. CÁNOVAS DEL CASTILLO (dir), Historia General de España, El Progreso editorial 1, Madrid, 652.

VILLAVERDE, V., 1994, Arte paleolítico de la Cova del Parpalló. estudio de la colección de plaquetas y cantos grabados pintados, Museu de Prehistòria de València, Diputació de València, 2 vols.

VILLAVERDE, V. and ROMÁN, D., 2004, Avance al estudio de los niveles gravetienses de la Cova de les Cendres. Resultados de la excavación del sondeo cuadros A/B/C-17 y su valoración en el contexto del Gravetiense mediterráneo ibérico, Archivo de Prehistoria Levantina XXV, 19-59.

VILLAVERDE, V., CARDONA, J. and MARTÍNEZVALLE, R., 2009, L'art pariétal de la grotte Les Meravelles. Vers une caractérisation de l'art paléolithique pré-magdalénien du versant méditerranéen de la Péninsule Ibérique,

L'Anthropologie 113, 762-793.

VILLAVERDE, V., ROMÁN, D., MARTÍNEZ VALLE, R., BADAL, E., BERGADÀ, M. M.,
GUILLEM, P. M., PÉREZ RIPOLL, M. and TORMO, C., 2010, El Paleolítico superior en el País Valenciano. Novedades y perspectivas, in X. MANGADO (ed), El Paleolítico superior peninsular. Novedades del siglo XXI, Monografies del SERP 8, Universitat de Barcelona, Barcelona, 45-73.

VILLAVERDE, V., ROMÁN, D., PÉREZ RIPOLL, M., BERGADÀ, M. M. and REAL, C., 2012, The End of the Upper Palaeolithic in the Mediterranean Basin of the Iberian Peninsula, Quaternary International 272-273, 17-32.

VILLAVERDE, V., REAL, C., ROMÁN, D. ALBERT, R. M., BADAL, E., BEL, M. A., BERGADÀ, M. M., DE OLIVEIRA, P., EIXEA, A., ESTEBAN, I., MARTÍNEZ-ALFARO, A., MARTÍNEZ-VAREA, C. and PÉREZ-RIPOLL, M., 2017, The early Upper Palaeolithic of Cova de les Cendres Alicante, Spain, Quaternary International 2017 https.//doi.org/10.1016/j. quaint.2017.11.051.

WENINGER, B. and JORIS, O., 2008, A 14C age calibration curve for the last $60 \mathrm{ka}$. the Greenland-Hulu U/Th timescale and its impact on understanding the Middle to Upper Paleolithic transition in Western Eurasia, Journal of Human Evolution 55, 772-781. 
